UDC 338.48:338.1

JEL R58

DOI: $10.31375 / 2226-1915-2019-2-131-142$
Matviienko M.

$\mathrm{PhD}$, associate professor of Entrepreneurship and Tourism department e-mail: marinimus029@gmail.com

ORCID https://orcid.org/0000-0002-5753-683X

Odessa National Marine University, Odessa, Ukraine

\title{
ECONOMY OF HOSPITALITY: HORECA EFFICIENCY IN UKRAINE
}

Abstract. The hospitality sector is one of the key factors of the European economy and European tourism, both in terms of employment and direct contribution to the economy. Together with tourism, the hospitality sector is the third largest socio-economic activity in the EU. Ukraine is gradually assimilated into the tourist map of Europe, therefore, the development of the sphere of hospitality becomes an urgent need for further development of the Ukrainian economic system.

The article is devoted to the research the hospitality industry role in the Ukraine economy and especially the coastal region, its potential and directions of development taking into account the features of internal and external tourism.

The hospitality sector is a number of fields within the service industry including lodging, food and drink service, event planning, theme parks, transportation, cruise line, traveling and additional fields within the tourism industry. The hospitality is a multibillion-dollar industry that depends on the availability of disposable income and leisure time.

The hospitality industry is a dynamic business area with a large number of categories, but customer service is a common factor to all segments of the industry. Different directions of the hospitality industry provide the integrity of the traveler's needs.

In the hospitality sector, the success of a business largely depends on how effective the team is and how effective the business model is. The cost of entering to the in-dustry is large enough, but the management or ownership of various hospitality enterprises allows to get high profits in the long run.

The hospitality industry is formed by several business areas, closely linked with both tourism and leisure activities. Accommodation is ranging from luxurious hotels to luxury resorts and camping. The accommodation is wide sector of the hospitality industry, ranging from bed and breakfast and hotel facilities to other facilities offering accommodation services. Accommodation is closely linked to other segments of the hospitality industry. Providing food and drink is another important area of the hospitality industry. This area is also quite broad about the possibility of building and doing business. The sector of food and beverages is the main industry. Business structures here can take a variety of forms from the bistro to the high-end restaurant.

Food is the foundation of the hospitality industry. It begins with the production of food and ends with the presentation of food on the table. It has several components for doing business.

Food Management: It starts with food production. In addition to the production, transportation and storage of food products, it is also part of this direction.

(C) Matviienko M., 2019 
DEVELOPMENT OF MANAGEMENT

AND ENTREPRENEURSHIP METHODS ON TRANSPORT, № 2(67), 2019
РОЗВИТОК МЕТОДІВ

УПРАВЛІННЯ ТА ГОСПОДАРЮВАННЯ

НА ТРАНСПОРТІ, № 2(67), 2019

Food presentation: people love to eat well-presented food. Drinks: in addition to general food, drink storage and representation, they are also included in the list of food and catering services. Restaurant management: it is the effective management that allows you to complete all the previous stages and ensure the customer returns to the restaurant over and over again.

The dynamics of development of hotel business enterprises, the main tendencies and opportunities for development are determined.

The results of the research suggest that this direction depends not only on political changes and economic realities, but also on the specific development of tourist regions, investment of the sphere at the local level, the creation of brands of cities, investments of individuals and legal entities in specific but interesting areas for the consumer tourism: gastronomic, religious, entertaining, extreme.

Keywords: tourism business, entrepreneurship, collective accommodation facilities, tourism, service, hospitality industry.

УДК 338.48:338.1

JEL R58

DOI: 10.31375/2226-1915-2019-2-131-142
М. Матвієнко

доцент кафедри «Підприємництво та туризм» e-mail: marinimus029@gmail.com

ORCID https://orcid.org/0000-0002-5753-683X

Одеський національний морський університет

\section{ЕКОНОМІКА ГОСТИННОСТІ: ЕФЕКТИВНІСТЬ НОRЕСА В УКРАЇНI}

Анотація. Сектор гостинності є одним з ключових факторів європейської економіки та європейського туризму, як з точки зору зайнятості, так $і$ прямого внеску в економіку. Разом з туризмом сектор гостинності є третьою за величиною сочіально-економічною діяльністю в $е$. Украйна поступово асимілюється в туристичну карту Свропи, отже розвиток сфери гостинності стає нагальною потребою подальшого розвитку української економічної системи.

Стаття присвячена дослідженню ролі індустрії гостинності в економічі Украӥни та особливо приморського регіону, ї̈ потенціалу та напрямків розвитку з врахуванням особливостей внутрішнього та зовнішнього туризму.

Індустрія гостинності тісно пов'язана з туристичним сектором і певними напрямками тісно переплетена з ним, але логіка ведення бізнесу та иільова аудиторія тут дещо відрізняється. По-перше, клієнтом вважається не лише, людина, що подорожує, але і людина, що просто знаходиться поза межами свого житла. Тобто як клієнти розглядаються як туристи, так і місиеві жителі. Подруге, іншим є прочес побудови бізнесу і підхід до просування продукту бізнесу.

Ключовими напрямкам індустрії гостинності залишаються готельний та ресторанний бізнес у їх широкому розумінні. Перший скоріше слід назвати індустрією розміщення людей, які тимчасово знаходяться поза домівкою. Сектор дає широкі можливості для ведення бізнесу різного рівня. Для Украӥни розвиток иього напрямку пов'язаний із необхідністю перебудови існуючого готельного фонду, побудови нових готелів та розвитку малого бізнесу через розширення мережі костелів та вдосконалення їх послуг. Також иікавою тенденцією для розвитку є передача оперативного управління готелем професійним компаніям. 
DEVELOPMENT OF MANAGEMENT

AND ENTREPRENEURSHIP METHODS ON TRANSPORT, № 2(67), 2019
РОЗВИТОК МЕТОДІВ

УПРАВЛІННЯ ТА ГОСПОДАРЮВАННЯ

НА ТРАНСПОРТІ, № 2(67), 2019

Розвиток ресторанного бізнесу також пов'язаний з широким колом форм ведення бізнесу та своєю специфікою просування продукту. Важливим кроком для підвищення ефективності иього напрямку в Украйні може стати створення бренду украӥнської кухні, створення брендів міст та заохочення капіталовкладень у июю cфpepy.

В статті проаналізовано динаміку розвитку підприємств готельного бізнесу, визначені основні тендениії та можливості для розвитку. Результати дослідження дозволяють зробити висновок про суттєву залежність даного напрямку не тільки від політичних зрушень та економічних реалій, але і від специфічного розвитку туристичних регіонів, інвестування сфери на місиевому рівні, створення брендів міст, інвестувань фізичних та юридичних осіб у вузькі, але цікаві для споживача сфери туризму: гастрономічний, релігійний, розважальний, екстремальний.

Ключові слова: туристичний бізнес, підприємництво, колективні засоби розміщення, туризм, послуга, індустрія гостинності.

УДК 338.48:338.1

JEL R58

DOI: 10.31375/2226-1915-2019-2-131-142
М. Матвиенко

доцент кафедры «Предпринимательство и туризм» e-mail: marinimus029@gmail.com

ORCID https://orcid.org/0000-0002-5753-683X Одесский национальный морской университет

\section{ЭКОНОМИКА ГОСТЕПРИИМСТВА: ЭФФЕКТИВНОСТЬ НОRЕСА В УКРАИНЕ}

Аннотация. Сектор гостеприимства является одним из ключевых факторов европейской экономики и европейского туризма, как с точки зрения занятости, так и прямого вклада в экономику. Вместе с туризмом сектор гостеприимства является третьей по величине соииально-экономической деятельностью в ЕС. Украина постепенно ассимилируется в туристическую карту Европь, следовательно, развитие сферы гостеприимства становится насущной необходимостью дальнейпего развития украинской экономической системы.

Статья посвящена исследованию роли индустрии гостеприимства в экономике Украины и особенно приморского региона, ее потенциила и направлений развития с учетом особенностей внутреннего и внешнего туризма.

Индустрия гостеприимства тесно связана с туристическим сектором и определенными направлениями тесно переплетена с ним, но логика ведения бизнеса и иелевая аудитория здесь несколько отличается. Во-первых, клиентом считается не только, человек, путешествует, но и человек, просто находится за пределами своего жилища. То есть, клиенты рассматриваются как туристы, так и местные жстели. Во-вторых, другим является процесс построения бизнеса и подход к продвижению продукта бизнеса.

Ключевыми направлениями индустрии гостеприимства остаются гостиничный и ресторанный бизнес в их широком понимании. Первый скорее следует назвать индустрией размещения людей, которые временно находятся вне дома. Сектор дает широкие возможности для ведения бизнеса разного уровня. Для Украины развитие этого направления связано с необходимостью перестройки существующего гостиничного фонда, строительства новых отелей и развития 
малого бизнеса через расширение сети хостелов и совершенствования их услуг. Также интересной тенденцией развития является передача оперативного управления отелями профессиональным компаниям.

Развитие ресторанного бизнеса также связано с широким кругом форм ведения бизнеса и своей спеиификой продвижения продукта. Важным шагом для повышения эффективности этого направления в Украине может стать создание бренда украинской кухни, создание брендов городов и поощрения капиталовложений в эту сферу.

В статье проанализирована динамика развития предприятий гостиничного бизнеса, определены основные тенденции и возможности для развития. Результаты исследования позволяют сделать вывод о существенной зависимости данного направления не только от политических сдвигов и экономических реалий, но и от специфического развития туристических регионов, инвестирования сферы на местном уровне, создание брендов городов, инвестирования физических и юридических лиц в узкие, но интересные для потребителя сферы туризма: гастрономический, религиозный, развлекательный, экстремальный.

Ключевые слова: туристический бизнес, предпринимательство, коллективные средства размещеени, туризм, услуга, индустрия гостеприимства.

Problem statement. The hospitality industry is growing very rapidly and contributing nearly $10 \%$ of the world's GDP [1]. In recent decades, the hospitality industry has become important for the economic development of not only individual countries, but also regions. The hospitality industry is transformed around the world and contributes to a significant increase in GDP. Hospitality is built on the regional, national and global levels. The specificity of this area is primarily determined by international orientation, deep diversification and high competition both at the local and regional levels. A large number of indicators indicate signs of economic growth in the industry. But forecasts show uneven growth (in developing countries $-6,4 \%$, in developed countries $-2,2 \%$ ), which indicates Ukraine's ample opportunities in this area. The hospitality industry consists of many sub-sectors, institutions, enterprises, which, in the case of an effective policy of development, can create a large number of jobs at the level of small, medium and large businesses. Today, the direction of the hotel and restaurant business is one of the most sources of economic growth. But hospitality industry may include other sectors (fig. 1).

As can be seen from Figure 1, the terms tourism and hospitality are interconnected and can be grouped together as one branch. However, these industries are two separate sectors. There is a certain convergence and crossing between them. Tourism is defined as the travel of people traveling to places outside of their usual recreation environment. Hospitality is the provision of accommodation, accommodation, food and drinks to those people who are out of the house. The services are used both by foreigners and citizens of the country. Both of these areas include restaurants, rooms, hotels and other exhibitions. Tourism is not a subsector of hospitality but a source of tourist services. 


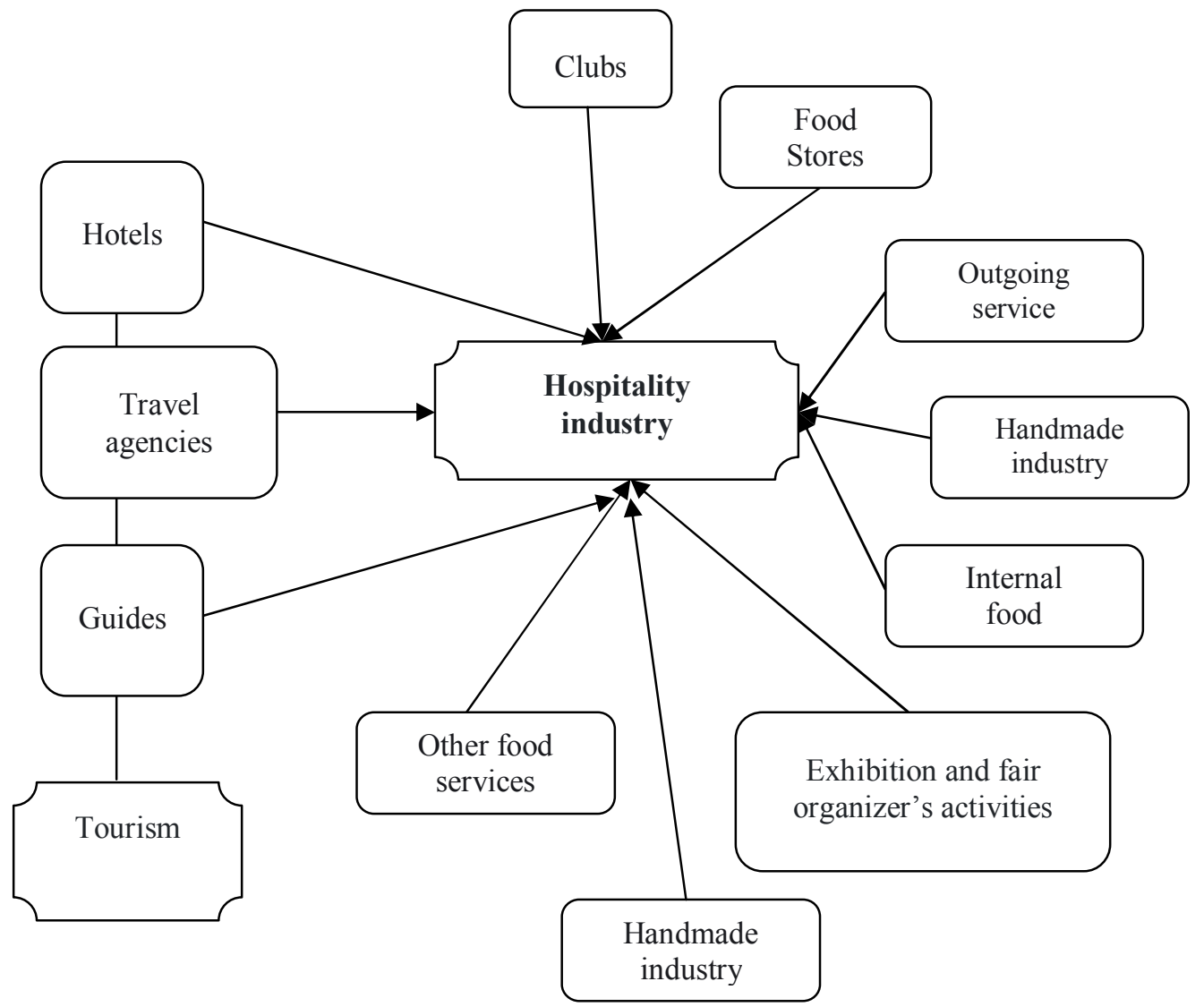

Source: Own elaboration

Fig. 1. Infrastructure of Hospitality industry

Hospitality industries provide services in a variety of ways. Hospitality is the center of those countries where tourism is the main export sector. The cross-flow of business people and tourists influences the development of the hospitality industry. Hospitality is the main source of foreign exchange and the largest employer. Hospitality brings together different cultures in the global community. Therefore, hospitality is not a concept, but it is the driving force in the world market. Lifestyle and business globalization lead to a departure from the political system and the difference in cultures. Global thinking and integrated approach are required from business in this area because of the hard internal and external competition and the attractiveness and swiftness of the scope. In these conditions, enterprises of restaurant and hotel business work. The slowdown in the development of this sphere is the perception of tourism and the hospitality industry as a whole and the low interest of business entities in creating the infrastructure of the hospitality industry due to lack of funds and low payback periods for investment objects. 
Tourism in Ukraine becomes an important area of activity, every year volume of tourist product sales grows, which entails the need of tourist placement, and the state tourism management is aimed at the formation of a competitive tourist and hotel complex. Nowadays the hotel industry of Ukraine is considerably inferior to the developed countries. But in general, in spite of a certain decrease in the rate of development of this business sphere, the company with a correctly selected model management, selected personnel and a competitive combination of price and quality continues to function. At the same time, it must be stated that the condition of the hotel's material and technical base needs to be reconstructed. It is one of the most significant problems in modern Ukrainian tourism. Also, a significant disadvantage is the lack of a strategy for building the hospitality industry, and the development of the hotel and restaurant complex in this direction.

Review of the last research and publications. In general, the situation in the Ukrainian tourism and hospitality industry is characterized by a large number of works national scholars such as T. Bozhydarnik, A. Vasilchenko, I. Voloshin, Z. Gerasimchuk, L. Matviychuk, O. Milashovsky. Opportunities of industry management is also well known.

A number of researchers are focused on the study of tourist flows [6], the size of which affects the competitiveness of both enterprises and territories, and tourism in general. The impact of various factors on the state hotel management is established by modern methods [1].
The issues of the hotel industry were considered by I. Voloshin, S. Gerasimchuk, A. Mazaraki, T. Tkachenko and other scientists. Especially one should note both theoretical and applied researches of such authors as A. Lozova [3], I. Ostapenko, D. Mamotenko [3], O. Milashko [4].

Tasks of research. The goal of the paper is to determine the main vectors of the development of the domestic market the hospitality industry. To achieve the goal by collecting and systematization of statistical and analytical information it is necessary to analyze the current state of the hotel and restaurant market in Ukraine, revealing the features of its structure and problems of functioning at the present stage.

The main research material. One in ten enterprises in the European non-financial business economy belongs to the tourism industries. The hospitality sector directly employs $80 \%$ of the total EU tourism workforce, and counts all together 1,9 million enterprises, from which 9 out of 10 are micro enterprises, employing fewer than 10 people [2]. But only from 10 to $20 \%$ travel with tour operator. Obviously most of these people work in the hospitality sphere.

Last few years the quantity of tourists grows all around the world and in Europe (table 1). War has stopped Ukrainian growing in tourism area for several years. But the situation is increasing last few years (figure 2).

Analysis of the different European countries shares in the general flow of tourists showed that Ukraine has lost approximately two-thirds its share due to events 2013-2014 and so far the growth is low (figure 2). But the overall trend remains, so you can expect significant growth in the future. 
DEVELOPMENT OF MANAGEMENT

AND ENTREPRENEURSHIP METHODS ON TRANSPORT, № 2(67), 2019
РОЗВИТОК МЕТОДІВ

УПРАВЛІННЯ ТА ГОСПОДАРЮВАННЯ

НА ТРАНСПОРТІ, № 2(67), 2019

Table 1

Arrivals of residents/non-residents at tourist accommodation establishments

\begin{tabular}{|l|c|c|c|c|c|c|c|c|c|}
\hline & 2009 & 2010 & 2011 & 2012 & 2013 & 2014 & 2015 & 2016 & 2017 \\
\hline $\begin{array}{l}\text { EU } \\
\text { (28 count- } \\
\text { ries) }\end{array}$ & 100 & 100 & 100 & 100 & 100 & 100 & 100 & 100 & 100 \\
\hline Bulgaria & 0,756 & 0,753 & 0,814 & 0,861 & 0,873 & 0,824 & 0,765 & 0,871 & 0,877 \\
\hline Czechia & 2,345 & 2,294 & 2,270 & 2,501 & 2,430 & 2,390 & 2,326 & 2,398 & 2,437 \\
\hline Denmark & 0,697 & 0,720 & 0,726 & 0,730 & 0,721 & 0,728 & 0,703 & 0,712 & 0,689 \\
\hline Germany & 9,376 & 9,694 & 9,554 & 9,911 & 9,721 & 9,699 & 9,305 & 9,108 & 8,948 \\
\hline Greece & 4,055 & 3,922 & 4,242 & 3,674 & 3,946 & 4,251 & 4,141 & 4,030 & 4,300 \\
\hline Spain & 15,237 & 15,640 & 16,108 & 15,735 & 15,413 & 15,455 & 14,807 & 15,781 & 15,645 \\
\hline France & 13,946 & 13,303 & 14,065 & 13,863 & 14,238 & 13,600 & 12,502 & 11,566 & 11,733 \\
\hline Croatia & 2,706 & 2,410 & 2,446 & 3,317 & 3,335 & 3,376 & 3,351 & 3,526 & 3,737 \\
\hline Italy & 15,983 & 15,861 & 16,043 & 15,943 & 15,557 & 15,241 & 14,704 & 14,603 & 14,516 \\
\hline $\begin{array}{l}\text { Nether- } \\
\text { lands }\end{array}$ & 3,856 & 3,942 & 3,820 & 3,806 & 3,956 & 4,110 & 4,009 & 4,072 & 4,299 \\
\hline Austria & 7,203 & 6,957 & 6,822 & 6,939 & 6,742 & 6,566 & 6,290 & 6,349 & 6,213 \\
\hline Poland & 1,501 & 1,498 & 1,491 & 1,629 & 1,623 & 1,615 & 1,520 & 1,641 & 1,632 \\
\hline Portugal & 2,503 & 2,447 & 2,455 & 2,454 & 2,600 & 2,860 & 2,896 & 3,176 & 3,430 \\
\hline Finland & 0,863 & 0,840 & 0,887 & 0,909 & 0,866 & 0,806 & 0,700 & 0,717 & 0,763 \\
\hline Sweden & 1,887 & 1,793 & 1,692 & 1,617 & 1,557 & 1,610 & 1,674 & 1,685 & 1,641 \\
\hline $\begin{array}{l}\text { United } \\
\text { Kingdom }\end{array}$ & 7,550 & 7,419 & 7,170 & 7,149 & 6,928 & 10,468 & 11,828 & 11,183 & 10,523 \\
\hline Ukraine & 8,083 & 7,679 & 7,239 & 7,528 & 7,636 & 3,752 & 3,320 & 3,430 & 3,413 \\
\hline
\end{tabular}

Source: statistic sources

The dynamics of growth and market share are also significantly affected by the level of competitiveness of hotels and the restaurant sector, as this market is one of the most dynamic. Recently, construction of hotels in the world has reached enormous proportions, which cannot be said about Ukraine.

In Ukraine, the number of hotels and similar facilities from 2013 to 2017 has decreased from 3582 to 2474 [6], which is $30,9 \%$ in percentage terms. The dynamics of changes is shown in Fig. 4.

As can be seen, in only 4 years the number of collective accommodation facilities in our country has decreased more than one and a half times, while specialized facilities were reduced faster (1,8 times) than hotels (in 1,4 times). 
DEVELOPMENT OF MANAGEMENT AND ENTREPRENEURSHIP METHODS ON TRANSPORT, № 2(67), 2019
РОЗВИТОК МЕТОДІВ

УПРАВЛІННЯ ТА ГОСПОДАРЮВАННЯ

НА ТРАНСПОРТІ, № 2(67), 2019

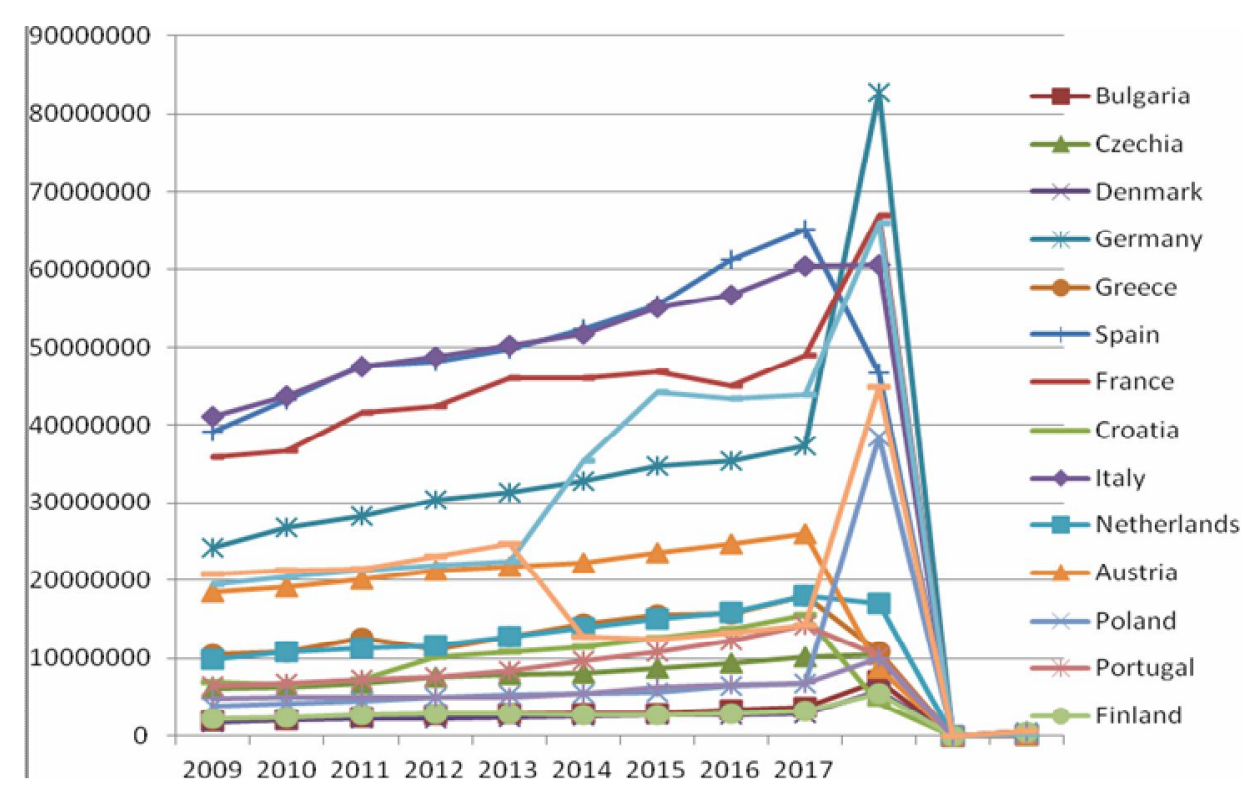

Fig. 2. Dynamics of tourism growing in Europe

Source: Own elaboration

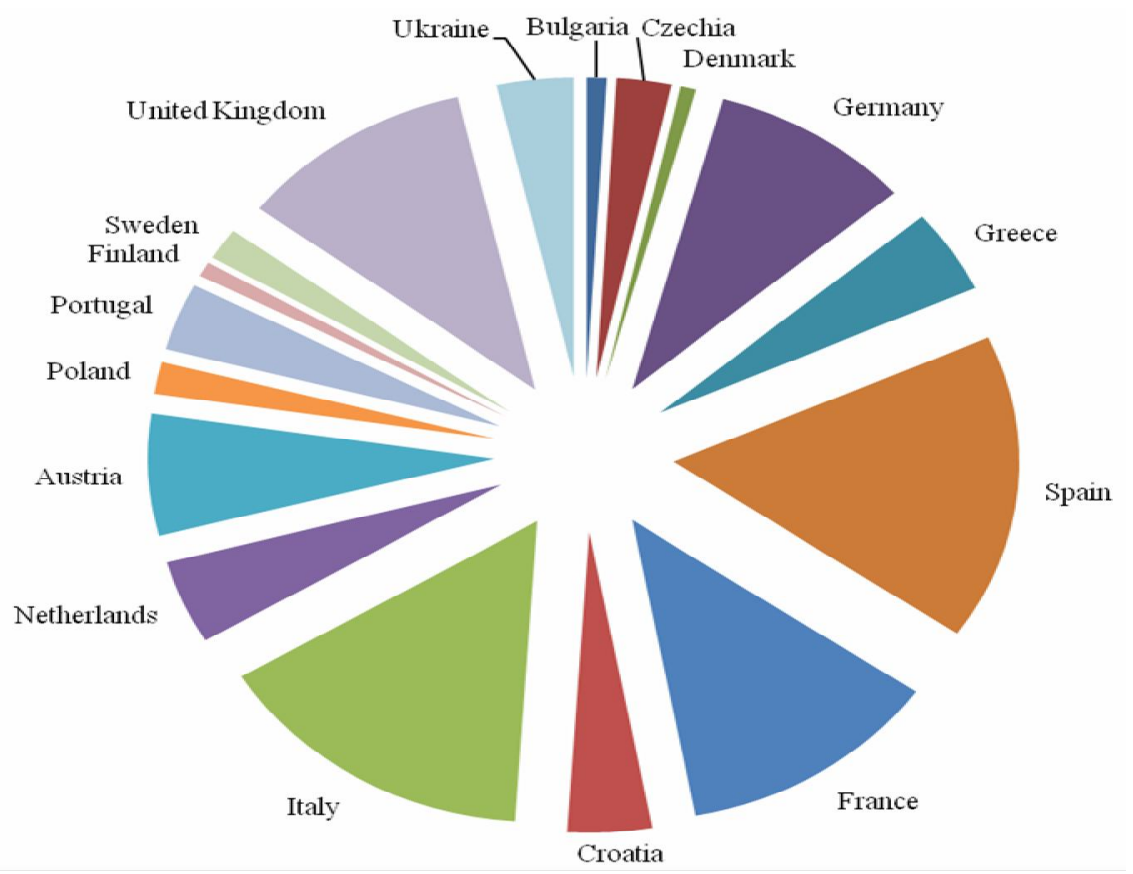

Fig. 3. Structure of total European touristic flow

Source: Own elaboration 


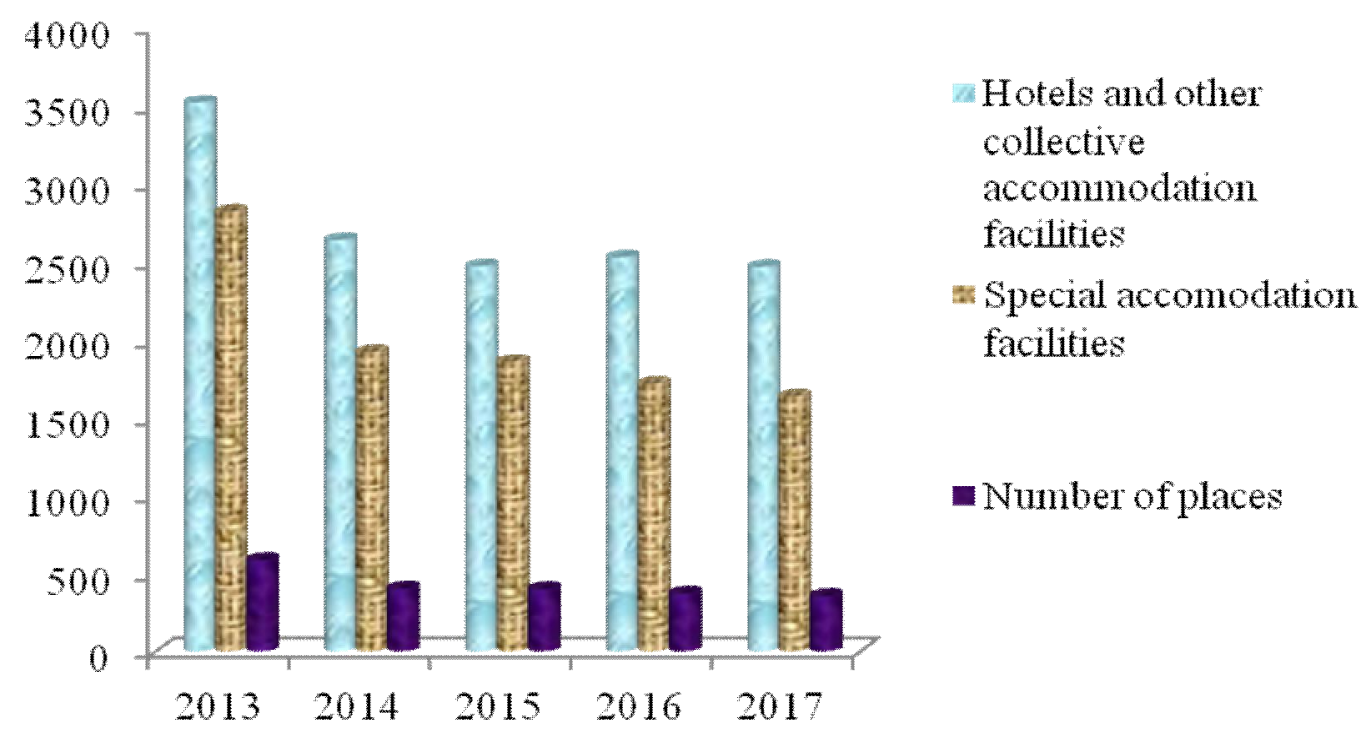

Fig. 4. Dynamics of collective accommodation in Ukraine for 2013-2017 years

In this case, the number fund from the end of 2013 to the end of 2017 , decreased from 586.6 thousand to 359,0 thousand places.

According to the State Statistics Committee of Ukraine, by the end of 2017 there are 4,113 thousand establishments with a total capacity of 359,0 thousand places, which annually serve about 6,7 million people, $77 \%$ of whom used the services of hotels (fig. 5).

In this case, the statistics do not fall «small hotels», which are rapidly opening in the residential sector, other types of hotel-type enterprises. Therefore, it is not surprising that according to various online services in Ukraine there are 5 to 10 thousand hotels.

Ukraine is one of the largest countries in Europe both in terms of territory and population. Natural and climatic conditions contribute to tourism, but only three tourists come from every ten residents, 23 tourists with an average of 1 square kilometer, while in Austria, which does not have a coastline at all, 29 tourists per 10 inhabitants, 300 tourists per square kilometer.

If we compare Ukraine with other European countries taking into account the size of the territory, then we can conclude that the hotel fund is inadequate, and taking into account the uncompetitiveness of many hotels and their low class, the insufficiently developed service of renting apartments, we can talk about one of the development directions of the hospitality sector hotel service improvement, diversification in the field of placement services.

The results of analyzing the restaurant sector shows that two of the top ten restaurants in the world belongs to France, Spain and the United Kingdom (Maison Lameloise, L'Auberge de l'Ill, Martín Berasategui, El Celler de Can Roca, The Black Swan, Belmond Le Manoir aux Quat'Saisons). 


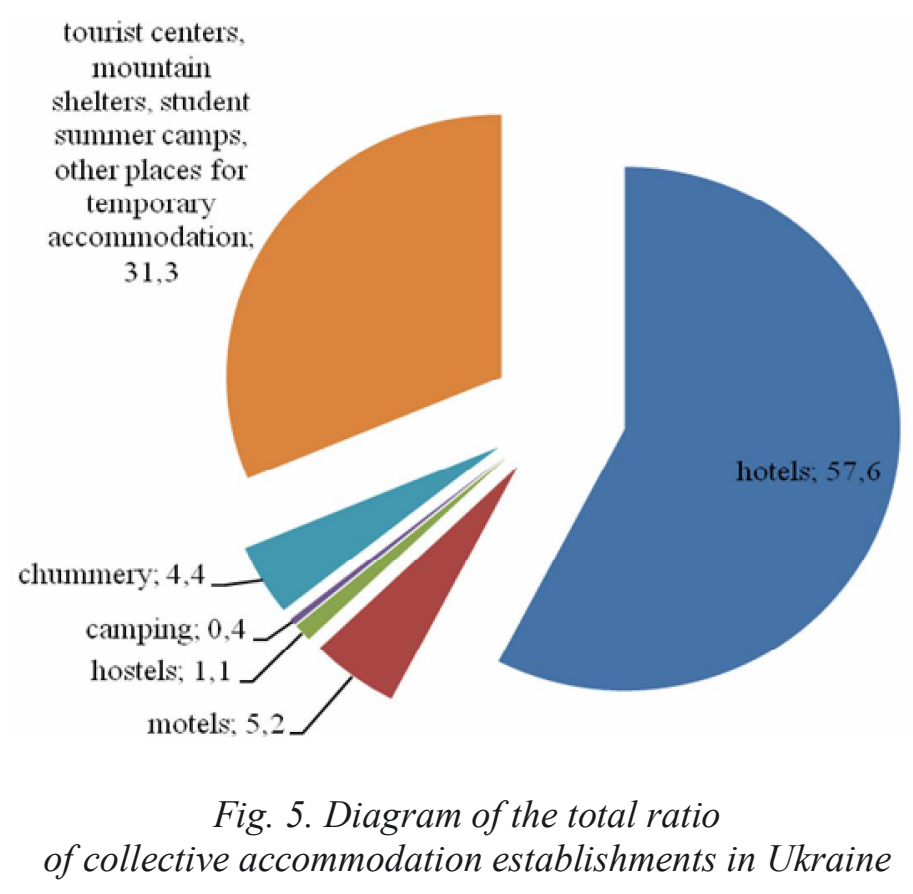

Source: Own elaboration

Ukraine has one of the most delicious cuisines in Europe, but does not have its own brand, like French cuisine. In addition, in the tourist centers, restaurants offer a variety of cuisine. Many tourists mark hospitality and a high level of dining, but after a while they cannot call the name of that small restaurant. Also, a significant disadvantage of many domestic restaurants is the level of service, although in recent years it has slightly risen. One more restraining factor is the life cycle of domestic restaurants - on average, two years. During this time it is difficult to create a brand and get a high score. Thus, we have another direction of increasing the hospitality industry - creating our own brand of Ukrainian cuisine at different levels and improving the level of service.

Conclusion. In conclusion we can say that during the last few years, due to military actions, difficult political situation and temporary occupation of the territory of the Autonomous Republic of Crimea and part of Ukraine, the tourist flow has decreased.

The conducted dynamics analysis of hotels and restaurants number in Ukraine and Europe, as well as the tendencies of changing the hotel fund allow us to conclude that hospitality industry is an effective field of investment, as it develops at a rather rapid pace, determines the level of employment in the regions concerned, creates a material base for the development of tourism. 
Hospitality is the main point in those countries where tourism is the major export industry.

The hospitality is the main source of foreign currency exchange and largest employers to employ the workforce. Hospitality brings the different cultures together in global community. It is also obvious that tourists and travelers are in demand of unique local products from the hospitality industry. Ukrainian restaurants can give this service to tourists so we need to create own Ukrainian brand, promote in on the different levels of business. Creating city brands also is one of the most impotent directions of hospitality industry so social entrepreneurship will be useful.

\section{REFERENCES}

1. Boella, M.J. (2000). Human Resource Management in the Hospitality Industry Nelson Thornes, 348.

2. The hospitality industry's contributions to European economy society. Retrieved from https://www. hotrec.eu/facts-figures

3. Lozova, O. \& Mamotenko, D. (2017). Suchasniy rozvitok gotelnogo gospodarstva $v$ Ukrayini [Contemporary development of the hotel industry in Ukraine]. Bulletin of the Kharkiv National Technical University of Agriculture named after Petr Vasilenko. Voice over 185, 251-259 [in Ukraine].

4. Milashko, O. (2014). KolektivnI zasobi rozmIschuvannya yak ob'Ekt statistichnogo vivchennya [Collective means of placement as an object of statistical study]. Bulletin of social and economic research, Vip. 2 (53), 202-206 [in Ukraine].

5. Voloshin, I.M. (2015). Perspektivi rozvitku turizmu v ukrayini ta sviti: upravlinnya, tehnologiyi, modeli [Prospects for the development of tourism in Ukraine and the world: management, technology, models: collective monograph] / in sciences. edit I. Voloshina. Lutsk: RVB of Lutsk National Technical University, 328 [in Ukraine].

6. Boshot, N.V. (2018). Trends in the development of the hotel industry in Ukraine. State and Regions - Series: Economy and Entrepreneurship, № 3 (102), 66-71.

7. Kosar, N. \& Kuzio, N. (2016). Research on the development of tourism in a crisis. Actual problems of the economy, vol. 2 (176), 115-125.

8. The official site of http://mkt.unwto.org/barometer United Nations World Tourism Organization (2018), «Statistics», available at: http://www2. unwto.org/.

9. The official site of http://mkt.unwto.org/barometer Eurostat (2018). Dynamics of tourist flows. Retrieved from http://ec.europa.eu/eurostat. 
DEVELOPMENT OF MANAGEMENT AND ENTREPRENEURSHIP METHODS

ON TRANSPORT, № 2(67), 2019
РОЗВИТОК МЕТОДІВ

УПРАВЛІННЯ ТА ГОСПОДАРЮВАННЯ

НА ТРАНСПОРТІ, № 2(67), 2019

10. The official site of http://mkt.unwto.org/barometer Entrepreneurship (2018). Retrieved from https://www.usnews.com/news/best-countries/ entrepreneurship-rankings.

11. The official site of http://mkt.unwto.org/barometerState Statistics Service of Ukraine (2018). Retrieved from http://www.ukrstat.gov.ua.

Стаття надійшла до редакиії 07.06.2019

Reference a JournalArtic: Matviienko, M. (2019). Economy of hospitality: horeca efficiency in Ukraine. Development of management and entrepreneurship methods on transport, 2(67), 131-142. DOI: 10.31375/2226-1915-2019-2-131-142. 